\title{
IMPROVEMENT OF PRODUCT BOTTLED WATER QUALITY THROUGH SIX SIGMA AND FUZZY MARKETING MIX APPROACHES
}

\section{PENINGKATAN MUTU PRODUK AIR MINUM DALAM KEMASAN DENGAN PENDEKATAN METODE SIX SIGMA DAN FUZZY MARKETING MIX}

\author{
Maria Ulfah $\left.^{1,2}\right)^{*}$, Faula Arina ${ }^{1)}$, and Dyah Lintang Trenggonowati ${ }^{1)}$ \\ ${ }^{1)}$ Department of Industrial Engineering, Faculty of Engineering, Sultan Ageng Tirtayasa University, \\ Jendral Sudirman Street, Cilegon 42434, Banten, Indonesia \\ E-mail: maria67_ulfah@yahoo.com \\ ${ }^{2}$ Indonesia Center of Excellence for Food Security (Local Food Innovation), Sultan Ageng Tirtayasa University \\ Makalah: Diterima 10 September 2020; Diperbaiki 25 Desember 2020; Disetujui 17 Januari 2021
}

\begin{abstract}
ABSTRAK
Dari data hasil penjualan tahun 2019, jumlah penjualan air minum dalam kemasan Baros 19 L mengalami penurunan sebanyak 26.304 unit. Tujuan penelitian ini adalah untuk mengetahui tingkat sigma yang menunjukkan level kinerja perusahaan secara keseluruhan dengan six sigma. Metode Fuzzy Marketing Mix dapat menunjukkan mutu pelayanan yang masih belum memuaskan pelanggan, sehingga dapat dilakukan perbaikan. Pendekatan metode Six Sigma memiliki tahapan DMAIC, yaitu Define, Measure, Analyze, Improve, dan Control. Hasil dari tahap define untuk pemetaan atribut dimensi Marketing Mix 4P (product, price, promotion, dan place) sebanyak 27 atribut dan dilakukan pengukuran voice of costumer kepada 100 responden. Tahap measure mendapatkan gap kesenjangan negatif terbesar antara kepuasan dan kepentingan, yaitu pada atribut 23 sebesar -0,4452. Berdasarkan hasil perhitungan DPMO dan tingkat sigma dari tingkat kepuasan pelanggan didapatkan rata-rata nilai sigma produk air minum dalam kemasan sebesar 2,561 dengan rata-rata DPMO sebesar 153.204. Tahap analyze menemukan variabel utama penyebab terjadinya ketidakpuasan pelanggan untuk segera dapat dilakukan perbaikan. Atribut dengan gap negatif dan nilai DPMO terbesar yaitu keterlambatan pengiriman produk air minum dalam kemasan kepada konsumen (atribut 23), sehingga menjadi fokus untuk perbaikan. Perbaikan yang dapat dilakukan untuk meningkatkan mutu produk air minum dalam kemasan 19 L adalah memastikan ketersediaan kemasan botol baru untuk setiap sopir yang kekurangan botol kosong.
\end{abstract}

Keywords : fuzzy, marketing mix, kualitas, six sigma

\section{ABSTRACT}

According to 2019 annual sales data, the amount of Baros 19-liter bottled water sales experienced 26,304 units drop. The objective of this research was to determine the level of sigma which indicates the level of overall company performance with Six Sigma and with Fuzzy Marketing Mix method to see which service quality that is still not satisfying the customers so that improvements can be made. The Six Sigma approach was done through DMAIC steps, which were define, measure, analyze, improve, and control. The result from the define step, which was mapping of attribute dimensions Marketing Mix 4P ((product, price, promotion, and place), was 27 attributes and voice of customer measurement was done with 100 respondents. The measure step found that the biggest negative discrepancy with the value of -0.4452 was between satisfaction and importance in attribute 23 . Based on calculation of DPMO and the sigma level, the average Sigma score of bottled water in Indonesia was 2.561 with average DPMO of 153,204 . In the analysis step, it was conducted to find the main variable that causes customer dissatisfaction to be repaired immediately. Attribute with the highest negative discrepancy was delayed in product delivery to the costumers (attribute 23). Improvement that can be done to increase the product quality of 19-liter bottled water was to ensure availability of new water bottle for every driver lacking empty bottle.

Keywords : fuzzy, marketing mix, quality, six sigma

\section{INTRODUCTION}

PT. Banyu Reverse Osmosis (PT. Baros) is a bottled drinking water company, producing "Baros" brand drinking water. Two main products are drinking in 19 liter bottle and in 250 milliliter cup. According to production data in 2018, PT. Baros successfully sold 276,667 units of 19-liter bottled water to the consumers, whereas in 2019 , the total sales was 250,363 units. From the aforementioned data, it can be seen that the number of sales had rapidly declined for Baros 19-liter bottled water. In 2019, Baros 19-liter bottled water product experienced decline in sales of about 26,304 units or around $10 \%$ compared to 2018. From the results of interviews with the marketing manager of PT. Baros, the decline in sales was caused by customers to unsubscribe due to unsatisfactory product service quality, including late product delivery. 
With the rapid technological advancements, drinking water provision is also advancing, for example, availability as bottled water. The high number of rising bottled water companies create higher competition between producers. After experiencing such rapid advancement, now drinking water producers must be extra careful (Syamsul, 2010). The very determining factor of a company to be able to survive in the multidimensional crisis that Indonesia is currently experiencing is making a marketing strategy according to customer desires (Munandar et al, 2004). Consumers will choose drinking water with good quality and price that is corresponding to the product quality, along with the benefit from consuming the drinking water (Ningsih et al., 2016), so that companies should understand completely the needs of consumers out of the produced products (Amrina and Fajrah, 2015). By this problem, PT. Baros must improve on its 19-liter bottled water product quality to avoid further sales declining.

In this research, improvement on 19-liter bottled water product quality will be done through Six Sigma and Fuzzy Marketing Mix methods. The Fuzzy Marketing Mix approach was chosen in accordance with Aly and Vrana (2005) in order to solve the instability and uncertainty problems on the Marketing Mix in a company. Marketing is regarded as the primary factor in product survivability in the market (Vorhies et al., 2009).

Six Sigma is a way of measuring the process to meet near perfect goal, presented with 3.4 Defect Per Million Opportunities (DPMO), and it is an approach to changing organizational culture. One of the methodologies in an effort to improve on Six Sigma targets is DMAIC (Define, Measure, Analyze, Improve, dan Control) which provides a step in finding the problem, identifying the cause of the problem until finally finding a solution to fix it. As a step in using this DMAIC method, it is necessary to describe the performance of a process, namely through process control charts and fishbone diagram (Kartini and Jayanthi, 2019). Six Sigma is a continuous improvement effort to decrease variations on process, to increase the process capability to produce products (and/or service) which is zero defects, with minimum target of 3.4 DPMO and to ensure customer value (Hutahean, 2018).

Kotler (2006) defines the Marketing Mix as a mix of marketing variables that can be controlled and used by company for pursuing the expected sales in target market (Isyana et al., 2017). The Marketing Mix has many elements that can be specified according to the main goal of the organization, main elements of marketing mix refer to the $4 \mathrm{P}$ (product, price, place or distribution, and promotion). These elements of marketing mix may strengthen the customer satisfaction's level (Thabith and Raewf, 2018). The variables in the Marketing Mix will be connected to one another (Singh, 2012).
The correlation between target, economical condition, development, and other input variables on one hand and control of marketing mix on the other hand is non-linear and difficult or cannot be defined correctly unless it is stated in the form of decision. One of the methods to handle all of the mix marketing problem aspects is to utilize fuzzy logic set, which effectively handle unclear, uncertain, and subjective inputs while also efficiently modelling the nonlinear correlation between input and output of the problem (Aly and Vrana, 2005).

FMEA (Failure Modes and Effects Analysis) is a structured procedure for identifying and preventing as many as possible modes of failure (failure mode). It is used to identify the sources and root causes of a quality problem. A failure mode includes the defect or failure in design, conditions outside the limits of the specifications has been defined, or changes in the product that causes disruption of the function of the product (Ulfah et al., 2019). The failure mode suggests to analysing the consequences of a process and its effects on the company (Fitriana et al., 2020). As an engineering technique, it is used to determine, identify, and eliminate known failures, problems, and errors of a design, process, and/or services before it reaches the consumers (Hanif et al., 2015). The advantage of FMEA is that it is an analytical tool that can evaluate reliability by examining failure modes and is one of the systematic techniques for analyzing failures (Ulfah et al., 2016).

Fuzzy FMEA is a development from conventional FMEA method which shows flexibility for uncertainties due to vague information or subjective preference element which was used in the scoring of the failures. Addition of fuzzy concept to FMEA algorithm allows both linguistics and numeric data to be used, which will have membership value in each of its attribute (Iqbal et al., 2013). Three main steps in fuzzy FMEA, which are (Suryoputro et al., 2018):

a. Fuzzification, process with linguistic variable to convert risk factors severity, occurrence, and detection into fuzzy. Through linguistic variable along with definition, followed with ranking the three factors with base scale to obtain membership degree in each class.

b. Rule evaluation contains knowledge from the experts about failure mode interactions and the effects of it in fuzzy rule "if then". This rule is easier to formulate in linguistic rule compared to numeric.

c. Defuzzification, process of creating ranking from fuzzy RPN to give failure mode priority ranking. Defuzzification process utilizes centroid method.

From the previous studies, the authors did not find research which used six sigma and fuzzy marketing mix approaches. Ganguly (2012) used six sigma approach with DMAIC methodologies in the project to determine the project's CTQ 
characteristics, defining the possible causes, identifying the variation sources, establishing variable relationships and implementing control plans. Other previous study, Azhar et al. (2019) utilized marketing mix approach and service quality. This study aims to investigate the effect of the marketing mix and service quality to tourist satisfaction and loyalty. The result showed that marketing mix had a positive and significant effect on tourist satisfaction in the region of Samosir.

Paramita et al. (2015) and Prameswara et al. (2014) used Servqual approach with the tangible, reliability, responsiveness, assurance, and empathy as dimensions They applied the "Define" step of Six Sigma. This research made some modification to replacing the dimension with 4P dimensions (product, price, promotion, and place) which is known as marketing mix theory. The six sigma and fuzzy marketing mix approaches was used to get better better improvement on product quality. The advantages of the six sigma method can improve product quality and increase the number of sales to consumers, while the advantages of fuzzy marketing mix approach can assess consumer satisfaction from the product. Six Sigma approach determined Sigma level in the scale of 1-6, if the scale was below Six Sigma terminology target, quality improvement was done through Fuzzy Failure Mode Effect Analysis (FFMEA) method. Fuzzy FMEA is the developed of conventional version and has been implemented in several researches (Rahmatin et al., 2018). Fuzzy marketing mix approach was done to determine the attributes and to measure the discrepancy between importance and consumers satisfactory upon the product or the service.

The objective of this research was to determine the level of sigma which indicates the level of overall company performance with six sigma and with fuzzy marketing mix method, it can be seen which service quality is still not satisfying to customers so to that improvements can be made.

\section{RESEARCH AND METHOD}

The first step of this research was observation and direct interview with PT. Baros about the problems of the factory. Then, problem solving was done through Six Sigma method with DMAIC cycle. The second step were making of the questionnaire with Marketing Mix theory with 4P dimensions. The collected data was processed to include gap and DPMO and sigma calculation, root cause analysis, and strategic steps for improvement.

The questionnaire results from Baros 19-L bottled water consumers in Serang, Cilegon, and
Pandeglang area. The main focus of questionnaire data on quality attributes was about the consumers unsatisfactory. These attributes were then analysed to figure out the root cause and assess applicable improvement strategies. Strategies were assessed with fuzzy FMEA method in which the questionnaire filling process was done through interview and brainstorming with PT. Baros delivery manager. Flowchart Research stages that integrate all the methods used are shown in Figure 1.

\section{Data Processing Using The Six Sigma Approach}

Data processing used the six sigma approach with stages define, measure, analyze, and improve. At define stage, the questionnaire was compiled using dimensions from the markeing mix theory, namely product, price, promotion and distribution (place). At the measure stage, data processing was carried out to determine the score gap between the level of satisfaction and the level of importance using the fuzzy marketing mix method, as well as calculating the DPMO and the sigma level. At the analyze stage, a Cartesian diagram analysis was carried out using the IPA method, then continued by making a cause and effect diagram to identity the root cause of the problem. The improve stage was carried out using the Fuzzy FMEA method.

\section{Data Processing Using The Fuzzy Marketing Mix Approach}

The fuzzy marketing mix approach was used in the define stage of six sigma to find the gap between satisfaction and importance, calculating the DPMO value and the six sigma level. The stages in data processing using Fuzzy Marketing Mix to calculate fuzzification of the questionnaire results then defuzzification of the level of importance.

Fuzzification process is a process to translate crisp score into fuzzy language which was done with Overall Effectiveness Measure (OEM) formula which produces score $(\mathrm{a}, \mathrm{b}, \mathrm{c})$ or lower limits, middle limits and upper limits. OEM formula is as below (Rosyidah et al., 2015) :

$$
O E M_{i}=\left(\frac{1}{N}\right) x\left[\left(P M_{i}^{j} x P I^{1}\right)+\ldots+\left(P M_{i}^{j} x P I^{N}\right)\right](1)
$$

Where:

$$
\begin{aligned}
P M_{i}^{j}= & \text { Weights the fuzzy value of the } \mathrm{i}^{\text {th }} \text { to } \mathrm{j} \\
& \text { variable indicator } \\
\mathrm{PI}^{\mathrm{N}}= & \text { Relative importance } \\
\mathrm{I} & =1,2,3, \ldots \mathrm{N} \\
\mathrm{J} & =1,2,3, \ldots \mathrm{M} \\
\mathrm{N} & =\text { The number of respondents }
\end{aligned}
$$




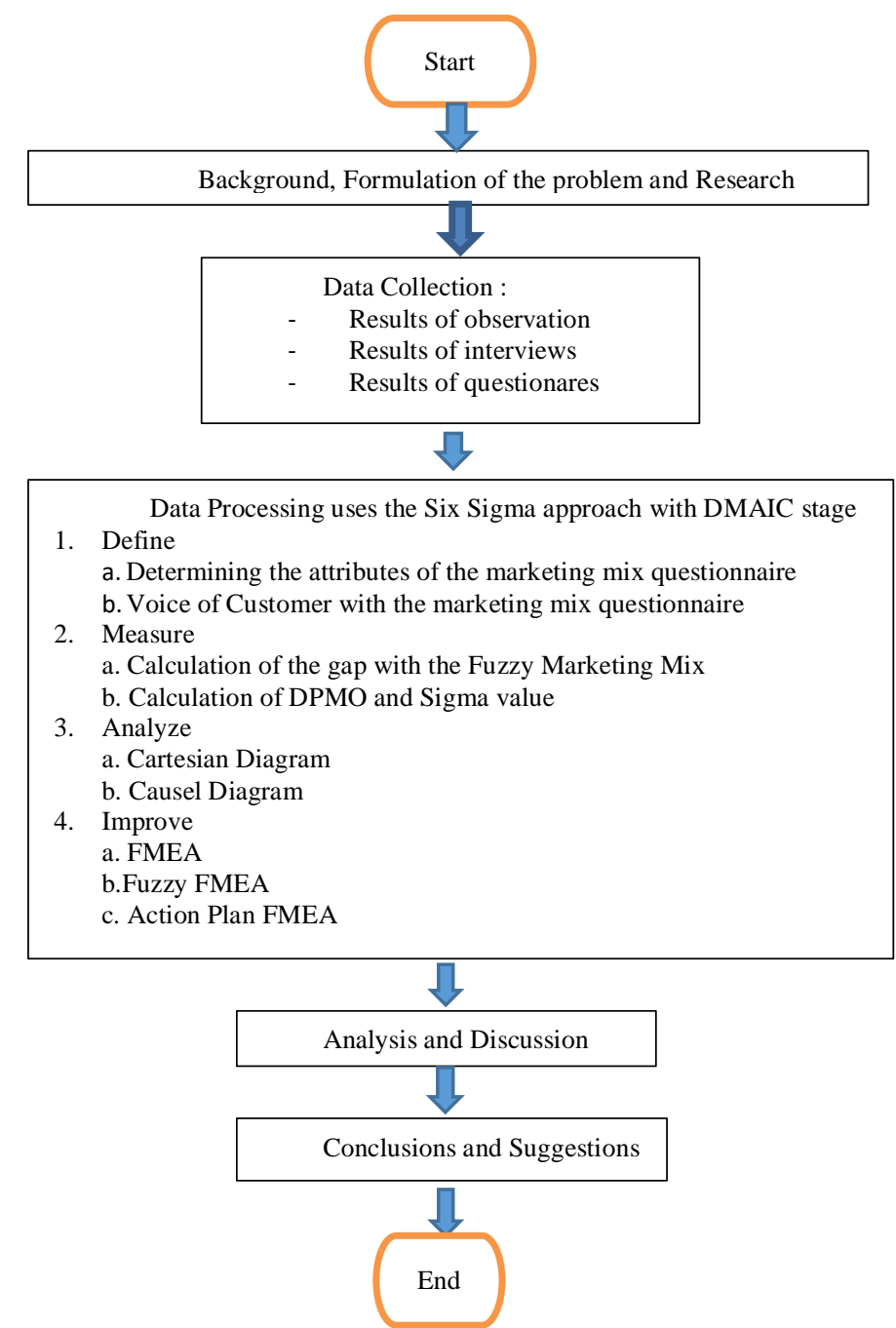

Figure 1. Research stages flowchart

Recapitulation of the research questionnaire scores was carried out first prior to the fuzzification stage. The satisfaction level data were obtained from the sum of each respondent's score of the criteria and scores, namely very dissatisfied (1), dissatisfied (2), quite satisfied (3), satisfied (4), and very satisfied with a score of (5).

The next step is to calculate the defuzzification value of the satisfaction and importance levels. It is to transform and restate the output of fuzzy domain into crisp domain which got a single representative value. Then, the gap calculation for each attribute was carried out based on the difference between the defuzzification value of the satisfaction and the importance levels. The gap value was used to determine the product marketing mix at the PT.Baros. Defuzzification was done with geometric mean formula:

Defuzzification $=\left(a_{i} \times b_{i} \times c_{i}\right)^{1 / 3}$

Explanation $: a_{i}=$ lower limits $b_{i}=$ middle limits (crisp)

$c_{i}=$ upper limits

\section{RESULT AND DISCUSSION}

\section{Define Step}

The define step of this research included Marketing Mix 4P attributes mapping in accordance with marketing mix theory and questionnaire filling process to 100 respondents (sample adequacy with Slovin formula). Attributes in Table 1 were determined from the 4 dimension of the marketing mix to measure customer satisfaction, begun with the mapping of marketing mix attributes to determine the voice of consumers through answering the questionnaire.

\section{Measure Step}

The measure step in this research consisted of Fuzzy Marketing Mix data processing to look for gap or discrepancy between satisfaction and importance, calculation of DPMO score, and Sigma level. 


\section{Gap Calculation with Fuzzy Marketing Mix}

The customer satisfactory analysis was done by calculating the discrepancy gap between satisfaction average score and importance average score. The steps in Fuzzy Marketing Mix data processing were by fuzzification calculation of the questionnaire result, followed by defuzzification of the satisfaction and importance levels.

Table 3 shows that all attributes have negative gap score. It means that the consumers still feel unsatisfied with Marketing Mix 19-liter bottled water of PT. Baros. Attribute that needs to be improved with the highest negative gap score was attribute 23 of distribution dimension. It is delivery of 19-liter bottled water to the consumers should be done in a quick manner. The consumers considered that the delivery or distribution was slow.

The form of triangular membership function of linguistic variable determining the fuzzy set used in the level of satisfaction are shown in Table 2.

\section{DPMO Score Calculation and Sigma Level}

The result of DPMO scores calculation and Sigma level are shown in Table 4. It can be seen that the average consumers satisfaction was $85 \%$, average DPMO of 153,204 and average Sigma level of 2.561.

Table 1. Marketing mix attributes mapping in Baros 19-liter bottled water product

\begin{tabular}{|c|c|}
\hline No & $x_{1}^{2}$ \\
\hline \multicolumn{2}{|r|}{ Product } \\
\hline 1 & The water in Baros $19 \mathrm{~L}$ bottled water is not dark or coloured \\
\hline 2 & The water in Baros $19 \mathrm{~L}$ bottled water does not have bad odour \\
\hline 3 & The health and hygiene of Baros $19 \mathrm{~L}$ bottled water is guaranteed \\
\hline 4 & The packaging of Baros $19 \mathrm{~L}$ bottled water is strong and not easily leaking \\
\hline 5 & The packaging of Baros $19 \mathrm{~L}$ bottled water is moss-free \\
\hline 6 & The packaging design of Baros $19 \mathrm{~L}$ bottled water is eye-catching \\
\hline 7 & The cap of Baros $19 \mathrm{~L}$ bottled water packaging is sealed and secured \\
\hline 8 & $\begin{array}{l}\text { Baros } 19 \mathrm{~L} \text { bottled water can compete with competitors/commercially available 19-liter bottled water } \\
\text { in the market }\end{array}$ \\
\hline No & Attributes \\
\hline 9 & Baros 19-liter bottled water has good product image in the market \\
\hline \multicolumn{2}{|r|}{ Price } \\
\hline 10 & The price of Baros $19 \mathrm{~L}$ bottled water is cheap in comparison to market \\
\hline 11 & The price of Baros $19 \mathrm{~L}$ bottled water is suitable with the offered quality \\
\hline 12 & The price of Baros $19 \mathrm{~L}$ bottled water is suitable with public purchase power \\
\hline 13 & The price of Baros $19 \mathrm{~L}$ bottled water is cheaper than other products \\
\hline \multicolumn{2}{|r|}{ Promotion } \\
\hline 14 & The promotion for Baros $19 \mathrm{~L}$ bottled water was done via online media \\
\hline 15 & The promotion for Baros $19 \mathrm{~L}$ bottled water was done via printed media \\
\hline 16 & PT. Baros gives discount for consumers with bulk order \\
\hline 17 & PT. Baros gives discount to regular consumers \\
\hline 18 & PT. Baros gives special lottery prize for consumer with most purchase \\
\hline 19 & Baros $19 \mathrm{~L}$ bottled water can be exchanged in case of product defects \\
\hline 20 & Promotion about Baros $19 \mathrm{~L}$ bottled water information was done by all employees to attract consumers \\
\hline 21 & PT. Baros provides best services on Baros $19 \mathrm{~L}$ bottled water delivery \\
\hline 22 & Free delivery charge for Baros $19 \mathrm{~L}$ bottled water for all consumers \\
\hline \multicolumn{2}{|r|}{ Distribution } \\
\hline 23 & Delivery of $19 \mathrm{~L}$ bottled water to the consumers is done in quick manner \\
\hline 24 & The stock availability of $19 \mathrm{~L}$ bottled water fulfils every request from the consumers \\
\hline 25 & The amount of vehicle used for the distribution of $19 \mathrm{~L}$ bottled water is adequate \\
\hline 26 & Distribution of $19 \mathrm{~L}$ bottled water to the consumers was done according to schedule \\
\hline 27 & PT. Baros responds to consumers' orders in quick manner \\
\hline
\end{tabular}




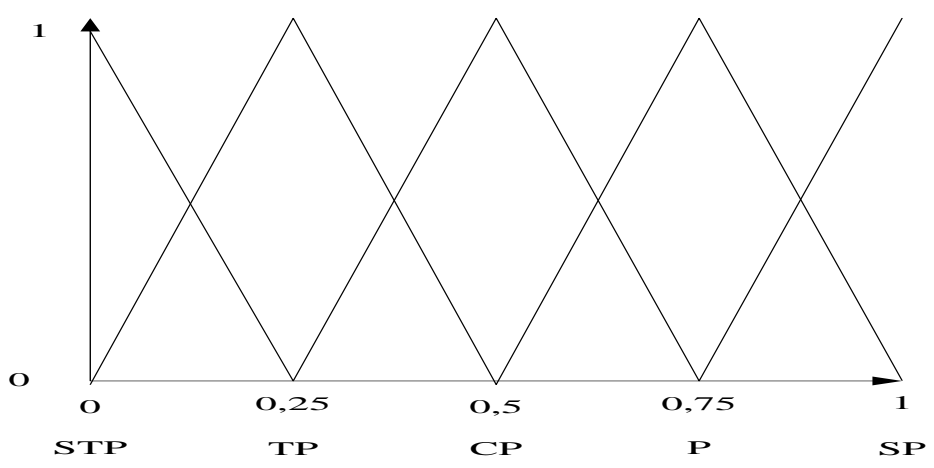

Figure 2. Satisfaction level lingustic variable membership function

Tabel 2. Triangular Fuzzy Number satisfaction level

\begin{tabular}{lccc}
\hline \multirow{2}{*}{ Satisfaction Level } & \multicolumn{3}{c}{ Triangular Fuzzy Number } \\
\cline { 2 - 4 } & Lower Limits & Midle Limits & Upper Limits \\
\hline Very Satisfied & 0.75 & 1 & 1 \\
Satisfied & 0.5 & 0.75 & 1 \\
Quite satisfied & 0.25 & 0.5 & 0.75 \\
Dissatisfied & 0 & 0.25 & 0.5 \\
Very dissatisfied & 0 & 0 & 0.25 \\
\hline
\end{tabular}

Table 3. Defuzzification result of satisfaction and importance level

\begin{tabular}{|c|c|c|c|c|c|c|}
\hline Dimension & Attribute & Satisfaction & Importance & Gap & Average & Rank \\
\hline \multirow{9}{*}{ Product } & 1 & 0.6105 & 0.822 & -0.2110 & \multirow{5}{*}{ - } & 10 \\
\hline & 2 & 0.6277 & 0.827 & -0.1994 & & 17 \\
\hline & 3 & 0.6105 & 0.811 & -0.2010 & & 15 \\
\hline & 4 & 0.5677 & 0.806 & -0.2386 & & 6 \\
\hline & 5 & 0.5704 & 0.800 & -0.2291 & & 8 \\
\hline & 6 & 0.6054 & 0.810 & -0.2042 & \multirow{4}{*}{0.1883} & 12 \\
\hline & 7 & 0.6385 & 0.761 & -0.1227 & & 26 \\
\hline & 8 & 0.6124 & 0.773 & -0.1603 & & 23 \\
\hline & 9 & 0.6301 & 0.759 & -0.1286 & & 24 \\
\hline \multirow{4}{*}{ Price } & 10 & 0.5426 & 0.777 & -0.2339 & \multirow{4}{*}{-0.2059} & 7 \\
\hline & 11 & 0.5880 & 0.788 & -0.2000 & & 16 \\
\hline & 12 & 0.5854 & 0.773 & -0.1874 & & 18 \\
\hline & 13 & 0.5795 & 0.782 & -0.2022 & & 14 \\
\hline \multirow{9}{*}{ Promotion } & 14 & 0.5281 & 0.745 & -0.2164 & \multirow{9}{*}{-0.1682} & 9 \\
\hline & 15 & 0.5667 & 0.693 & -0.1261 & & 25 \\
\hline & 16 & 0.4999 & 0.674 & -0.1741 & & 20 \\
\hline & 17 & 0.4923 & 0.701 & -0.2086 & & 11 \\
\hline & 18 & 0.4654 & 0.669 & -0.2036 & & 13 \\
\hline & 19 & 0.6589 & 0.819 & -0.1605 & & 22 \\
\hline & 20 & 0.6069 & 0.792 & -0.1849 & & 19 \\
\hline & 21 & 0.6107 & 0.778 & -0.1672 & & 21 \\
\hline & 22 & 0.7381 & 0.810 & -0.0720 & & 27 \\
\hline \multirow{5}{*}{ Distribution } & 23 & 0.3893 & 0.834 & -0.4452 & \multirow{5}{*}{$0.3660^{-}$} & 1 \\
\hline & 24 & 0.5254 & 0.829 & -0.3040 & & 4 \\
\hline & 25 & 0.5238 & 0.804 & -0.2800 & & 5 \\
\hline & 26 & 0.3922 & 0.824 & -0.4317 & & 2 \\
\hline & 27 & 0.4598 & 0.832 & -0.3721 & & 3 \\
\hline
\end{tabular}

(Source: Processed data, 2019)

The result of average DPMO and Sigma level indicated that PT. Baros for Baros $19 \mathrm{~L}$ bottled water was in the average category of Indonesian Industry. Defuzzification result and gap score of the 27
Marketing Mix attributes for $19 \mathrm{~L}$ bottled water in PT. Baros are shown in Table 3. 


\section{Analyze Step}

The analysis step of this research was started with Cartesian diagram to analyse in detail the important attributes for the consumers. Then, it was followed with the construction of root cause diagram or fishbone diagram in order to find the root cause of the dissatisfaction problem in attribute with highest discrepancy value.

\section{Cartesian Diagram Analysis}

The result of the Cartesian diagram is shown Figure 3. IPA (Importance Performance Analysis) method derives a matrix which contains four quadrants. The quadrant $\mathrm{I}$ is main concern of analysis, the consumers perceived condition and actual performance at the current state was seen unsatisfactory. According to Figure 3, there were five attributes in this category. The attribute 23 (delivery in quick manner), attribute 26 (distribution to the consumers according to schedule), attribute 27 (PT.Baros responds to consumers' orders in quick manner), attribute 24 (the stock availability to fulfil every request from the consumers), and attribute 25 (the adequity of vehicle used for the distribution). The Cartesian diagram showed that the attributes in quadrant I were belonged to distribution dimensions.

\section{Root Cause Diagram Analysis}

The fishbone diagram of attribute 23 , which was the cause of delivery delayed of the $19 \mathrm{~L}$ bottled water product to the consumer can be seen in Figure 4.

\section{Improve Step}

This step was done with FMEA, Fuzzy FMEA, and action planning FMEA. The interview and brainstorming with the delivery manager of PT. Baros, and the Fuzzy Risk Priority Number (FRPN) calculation in Matlab software of the cause of delivery delayed for $19 \mathrm{~L}$ bottled water product to the consumers are shown Table 5.

Table 4. DPMO score and sigma level calculation result

\begin{tabular}{|c|c|c|c|c|c|}
\hline Attribute & $\begin{array}{c}\text { Average } \\
\text { Satisfaction }\end{array}$ & $\begin{array}{c}\text { Satisfaction } \\
\text { Target }\end{array}$ & $\begin{array}{c}\text { Satisfaction } \\
\text { Level }\end{array}$ & DPMO & Sigma Level \\
\hline 1 & 3.600 & 4 & $90 \%$ & 100,000 & 2.782 \\
\hline 2 & 3.670 & 4 & $92 \%$ & 82,500 & 2.888 \\
\hline 3 & 3.600 & 4 & $90 \%$ & 100,000 & 2.782 \\
\hline 4 & 3.430 & 4 & $86 \%$ & 142,500 & 2.569 \\
\hline 5 & 3.440 & 4 & $86 \%$ & 140,000 & 2.580 \\
\hline 6 & 3.570 & 4 & $89 \%$ & 107,500 & 2.740 \\
\hline 7 & 3.700 & 4 & $93 \%$ & 75,000 & 2.940 \\
\hline 8 & 3.590 & 4 & $90 \%$ & 102,500 & 2.767 \\
\hline 9 & 3.670 & 4 & $92 \%$ & 82,500 & 2.888 \\
\hline 10 & 3.330 & 4 & $83 \%$ & 167,500 & 2.464 \\
\hline 11 & 3.500 & 4 & $88 \%$ & 125,000 & 2.650 \\
\hline 12 & 3.490 & 4 & $87 \%$ & 127,500 & 2.638 \\
\hline 13 & 3.470 & 4 & $87 \%$ & 132,500 & 2.615 \\
\hline 14 & 3.270 & 4 & $82 \%$ & 182,500 & 2.406 \\
\hline 15 & 3.420 & 4 & $86 \%$ & 145,000 & 2.558 \\
\hline 16 & 3.170 & 4 & $79 \%$ & 207,500 & 2.315 \\
\hline 17 & 3.140 & 4 & $79 \%$ & 215,000 & 2.289 \\
\hline 18 & 3.040 & 4 & $76 \%$ & 240,000 & 2.206 \\
\hline 19 & 3.780 & 4 & $95 \%$ & 55,000 & 3.098 \\
\hline 20 & 3.580 & 4 & $90 \%$ & 105,000 & 2.754 \\
\hline 21 & 3.590 & 4 & $90 \%$ & 102,500 & 2.767 \\
\hline 22 & 4.130 & 5 & $83 \%$ & 174,000 & 2.438 \\
\hline 23 & 2.770 & 4 & $69 \%$ & 307,500 & 2.003 \\
\hline 24 & 3.270 & 4 & $82 \%$ & 182,500 & 2.406 \\
\hline 25 & 3.260 & 4 & $82 \%$ & 185,000 & 2.396 \\
\hline 26 & 2.780 & 4 & $70 \%$ & 305,000 & 2.010 \\
\hline \multirow[t]{2}{*}{27} & 3.020 & 4 & $76 \%$ & 245,000 & 2.190 \\
\hline & & Average & $85 \%$ & 153,204 & 2.561 \\
\hline
\end{tabular}




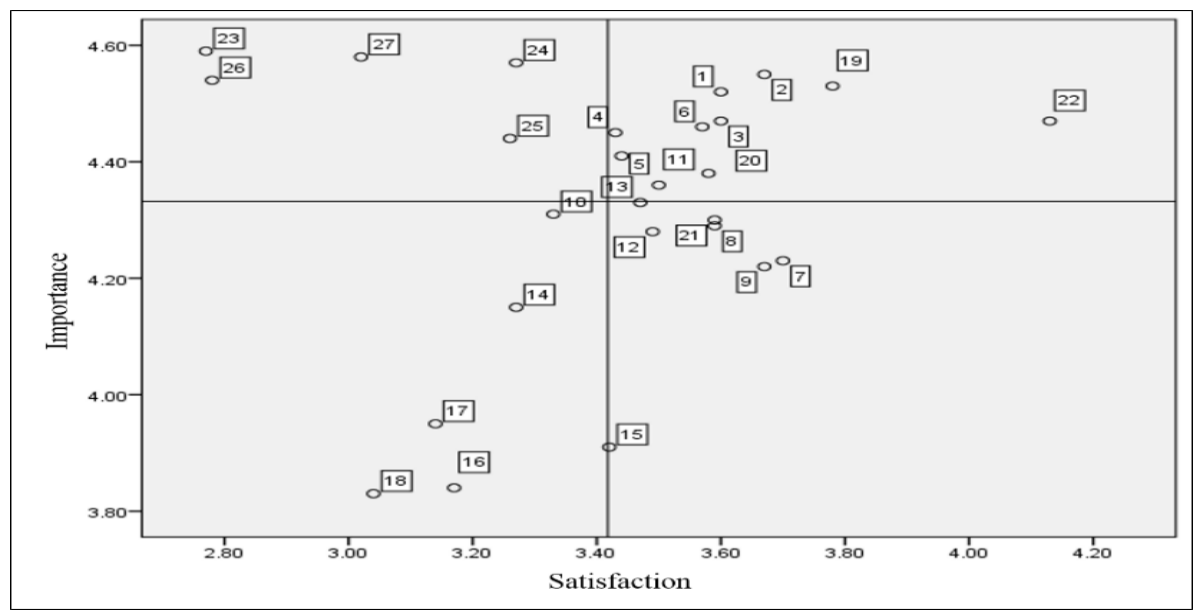

Figure 3. Cartesian diagram

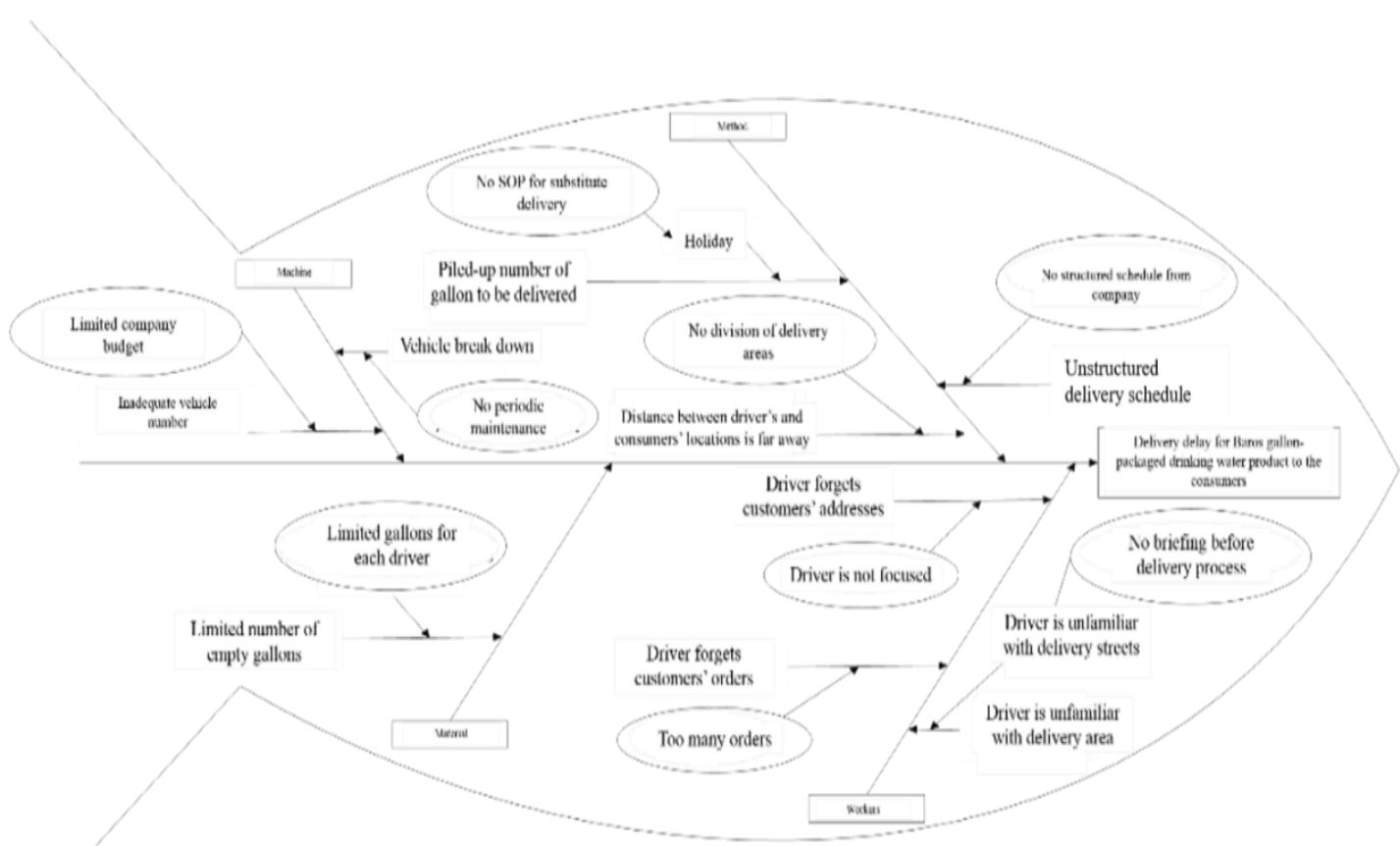

Figure 4. Root cause diagram of delivery delayed of PT. Baros 19 L bottled water Product

After determining FRPN score standardization, the next step is the implementation of the formulated recommended action. Action Planning for Failure Modes was made to determine appropriate actions, especially for failure modes with high failure risk. This improvement strategy was the result of interview and brainstorming between the researcher with the delivery manager and the delivery driver for Baros $19 \mathrm{~L}$ bottled water. The action planning FMEA for controlling the delivery delay of the $19 \mathrm{~L}$ bottled water products to the consumers is as shown Table 6 .

\section{Managerial Implications}

One of the contributions of this study was to provide recommendations to the company in the form of managerial implications as presented in Table 6 . There are various components involve for the management to response included quality, capacity, effectiveness, efficiency and policies that can contribute to increasing company productivity:

Quality

The Company can improve the quality of $19 \mathrm{~L}$ bottled water products based on responses from consumers regarding the level of quality satisfaction that are felt during the subscription. 
Table 5. FMEA of the cause of delivery delayed for Baros bottled water product to the consumers

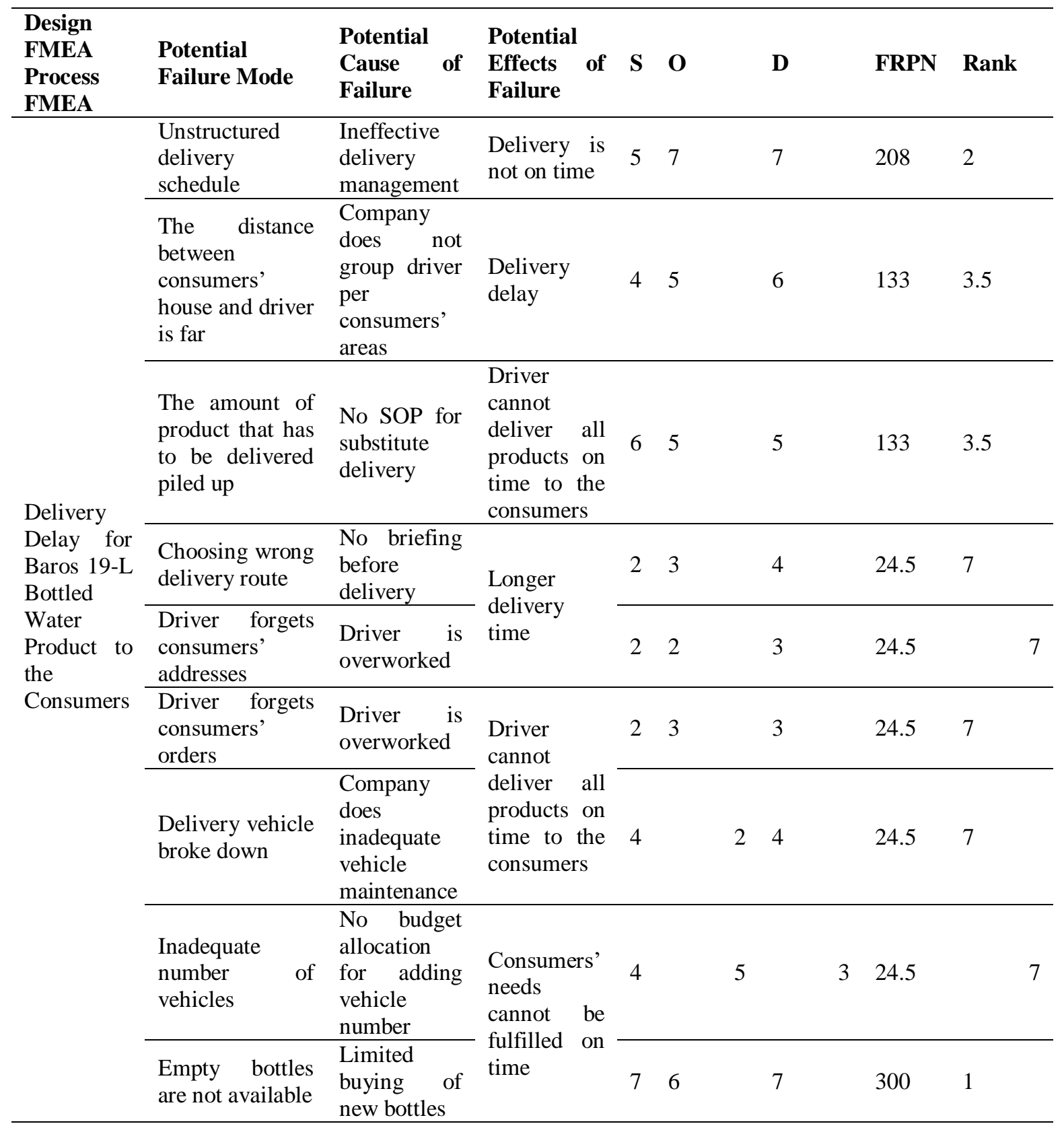

\section{Capacity}

Along with the quality improvement in product services, it will increase the number of sales and customer satisfaction, the production capacity will also increase.

\section{Effectiveness}

The proposed improvements effectiveness would be achieved as desired and could increase customer satisfaction. At the end, it is expected to reduce customer complaints, especially the distribution effectivity and efficiency.

\section{Efficiency}

The company should establish a more structured and planned delivery schedule to be more effective and efficient. It should be supported with SOPs dealing with the number of deliveries and creation of special routine maintenance schedules for delivery vehicles.

\section{Company Policy}

To improve quality and increase sales capacity, the company should establish policies to support company holding tour event to motivate drivers to be more enthusiastic. The should provide rewards for employees who work harder and are able to attract mor new customers. The company should make a policy to add the number of vehicles in order to be able to meet the increasing number consumer orders. 
Table 6. Action planning FMEA

\begin{tabular}{|c|c|c|c|c|}
\hline Rank & Mode of Failure & $\begin{array}{c}\text { Actionable } \\
\text { Cause }\end{array}$ & Design Action & Design Validation \\
\hline 1 & $\begin{array}{l}\text { Empty bottles } \\
\text { are not available }\end{array}$ & $\begin{array}{l}\text { Limited buying } \\
\text { of new bottles }\end{array}$ & $\begin{array}{l}\text { Adding the number of empty } \\
\text { bottle division to every } \\
\text { driver }\end{array}$ & $\begin{array}{l}\text { Raw material purchase } \\
\text { department provide new stock } \\
\text { of empty bottle for every } \\
\text { driver who lacks empty bottle }\end{array}$ \\
\hline 2 & $\begin{array}{l}\text { Unstructured } \\
\text { delivery } \\
\text { schedule }\end{array}$ & $\begin{array}{l}\text { Ineffective } \\
\text { delivery } \\
\text { management }\end{array}$ & $\begin{array}{l}\text { Create structured delivery } \\
\text { schedule }\end{array}$ & $\begin{array}{l}\text { Delivery section } r \text { creates } \\
\text { structured delivery schedule } \\
\text { for every driver with even are } \\
\text { division }\end{array}$ \\
\hline 3.5 & $\begin{array}{l}\text { The distance } \\
\text { between } \\
\text { consumers' } \\
\text { house and driver } \\
\text { is far }\end{array}$ & $\begin{array}{l}\text { Company does } \\
\text { not group driver } \\
\text { per consumers' } \\
\text { areas }\end{array}$ & $\begin{array}{l}\text { Divide the consumers' area } \\
\text { evenly }\end{array}$ & $\begin{array}{l}\text { Delivery section creates } \\
\text { structured delivery schedule } \\
\text { for every driver with even are } \\
\text { division }\end{array}$ \\
\hline 7 & $\begin{array}{l}\text { Inadequate } \\
\text { number of } \\
\text { vehicles }\end{array}$ & $\begin{array}{l}\text { No budget } \\
\text { allocation for } \\
\text { adding vehicle } \\
\text { number }\end{array}$ & Addition of vehicle number & $\begin{array}{l}\text { Finance department analyses } \\
\text { the budget to add the number } \\
\text { of vehicles }\end{array}$ \\
\hline 7 & $\begin{array}{l}\text { Delivery vehicle } \\
\text { broke down }\end{array}$ & $\begin{array}{l}\text { Company does } \\
\text { inadequate } \\
\text { vehicle } \\
\text { maintenance }\end{array}$ & $\begin{array}{l}\text { Create periodic maintenance } \\
\text { schedule for delivery vehicle }\end{array}$ & $\begin{array}{l}\text { Delivery section creates } \\
\text { periodic maintenance schedule } \\
\text { for every delivery vehicle }\end{array}$ \\
\hline 7 & $\begin{array}{l}\text { Choosing } \\
\text { wrong delivery } \\
\text { route }\end{array}$ & $\begin{array}{l}\text { No briefing } \\
\text { before delivery }\end{array}$ & $\begin{array}{l}\text { Before delivery process, } \\
\text { every driver attend briefing } \\
\text { to choose the correct } \\
\text { delivery route }\end{array}$ & $\begin{array}{l}\text { Delivery section creates } \\
\text { effective delivery route } \\
\text { instruction for every driver }\end{array}$ \\
\hline 7 & $\begin{array}{l}\text { Driver forgets } \\
\text { consumers' } \\
\text { orders }\end{array}$ & $\begin{array}{l}\text { Driver is } \\
\text { overworked }\end{array}$ & $\begin{array}{l}\text { Driver must utilize the } \\
\text { resting time effectively to } \\
\text { maintain focus while } \\
\text { working }\end{array}$ & $\begin{array}{l}\text { Company creates an event to } \\
\text { motivate the drivers to work }\end{array}$ \\
\hline
\end{tabular}

\section{CONCLUSION AND SUGGESTION}

\section{Conclusion}

The Sigma level of Baros 19-liter bottled water product was 2.561 which means the state of PT. Baros is in the average Indonesian Industry category. The attribute with the highest negative score gap and DPMO is attribute 23, delayed delivery to the costumers. Improvements that can be done to increase the product quality is to ensure availability of new water bottle for every day needs.

\section{Suggestion}

The company is expected to make improvements to minimize or reduce delays in delivery by increasing the sigma value. Furher research is needed to compare the quality of 19-liter bottled drinking water with other brands which should cover up with the control stage to estimate the implementation of the proposed improvements.

\section{REFERENCES}

Aly S and Vrana I. 2005. Fuzzy expert marketing-mix model. Quality Journal. 51(2) : 69-79.
Amrina E dan Fajrah N. 2015. Analysis of incompatibility of bottled drinking water products at PT Amanah Insanillahia. Journal Industrial System Optimization. 14(1): 99-115.

Azhar E, Jufrizen. Prayogi MA, Sari M. 2019. The role of marketing mix and service quality on tourist satisfaction andloyal at Samosir. Independent Journal Management. 5 (3) : 1663-1677.

Fitriana R, Kurniawan W, and Siregar JG. 2020. Food quality control with the application of good manufacturing practices (GMP) in the production process of dodol Betawi (Case Study SME MC). Jurnal Teknologi Industri Pertanian. 30(1): 110-127.

Ganguly, K. 2012. Improvement process for rolling mill through the DMAIC Sis Sigma approach. International Journal Quality Research. 6(3) : 221-231.

Hanif RY, Rukmi HS, and Susanty S. 2015. Improving the quality of luxury palace products at PT. X using the Failure Mode And Effect Analysis (FMEA) and Fault Tree Analysis (FTA ) methods . Online Journal the National Institute Technology. 3(3). 
Hutahaean and Raflesia E, 2018. Waste reduction and quality improvement bottled drinking Water products (AMDK) with the lean six approach sigma and weighted product. [Thesis]. Medan: Sumatra Utara University.

IA Kartini N and Jayanthi D 2018. Quality control analysis with six sigma-DMAIC method in effort reduce number of sugar products at PT. PG. Gorontalo. SINERGI. 8 (2) : 1-6.

Iqbal M, Muflikhah L, dan Setiawan NY 2013. Penggunaan Fuzzy Failure Mode and Effect Analysis (Fuzzy FMEA) dalam mengidentifikasi resiko kegagalan proses pemasangan dan perbaikan AC. Jurnal Informatika/Ilmu Komputer. 2 (7):1-6.

Munandar JM, Faqih U, and Meivita A. 2004. Analisis faktor yang mempengaruhi preferensi konsumen produk air minum dalam kemasan di Bogor. Jurnal Teknologi Industri Pertanian. 13(3): 97-107.

Ningsih FN, Sakdanur, dan Syabrus H. 2016. Effect of product quality and price against decision on the purchase of aqua brand bottled drinking water (study on university of Riau economics education study program students). [Thesis]. Riau: Riau University.

Paramita MS, Agustin W, Dania P, Ikasari DM. 2015. Pelayanan menggunakan metode servqual ( service dahlia " Pasuruan ) assessment of consumer satisfaction service quality using servqual method ( service quality ) and six sigma ( Case study in " Dahlia Restaurant " Pasuruan ). Jurnal Industria. 4(3) : 102-115.

Prameswara DA, Mustafid, dan Prahutama A. 2014. Metode servqual-six sigma untuk peningkatan kualitas pelayanan publik (Studi kasus di kantor Kecamatan Kedungbanteng, Purwokerto). Jurnal Gaussian UNDIP. 3(4) : 625-634.

Rahayu I, Ridho ND, and Fachrodji A. 2015. Marketing mix analysis of natural tourism area kawah putih and effect on visitors decision. Indonesian Journal Business and Entrepreneurship. 1(2) : $72-80$.

Rahmatin N, Santoso I, Indriani C, Rahayu S, Widyaningtyas S. 2018. Integration of the Fuzzy Failure Mode and Effect Analysis (Fuzzy FMEA) and the Analytical Network
Process (ANP) in marketing risk analysis and mitigation. International Journal Technology (2018) 4: 809-818 ISSN 2086-9614.

Rosyidah H, Wuryandari T, dan Rusgiyono A. 2015. Analisis kualitas pelayanan dengan menggunakan fuzzy servqual, kuadran IPA, dan indeks PGCV. Jurnal Gaussian. 4(4) : 885-894.

Singh M. 2012. Marketing mix of 4P'S for competitive advantage. IOSR Journal Business and Management. 3(6) : 40-45

Suryoputro MR, Khairizzahra, and Sari AD 2018. Failure mode and Effect Analysis (Fuzzy FMEA) implementation for forklift risk management in manufacturing company PT.XYZ. IOP Publishing. ISIEM 2018. IOP Conf. Series: Materials Science and Engineering 528: 012027.

Syamsul dan Muharti. 2010. Studi on physical quality of bottled drinking water (bottled water) before and after exposed by sunlight in Makassar. [Thesis]. Makassar: Alauddin Makassar Islamic University.

Thabith TH and Rewf MB. 2018. The evaluation of marketing mix elements: a case Study. International Journal Social Sciences \& Educational Studies. 4(4) : 100-109.

Ulfah M, Trenggonowati DL, Ekawati R, Ramadhania S. 2019. The proposed improvements to minimize potential failures using lean six sigma and multi attribute failure mode analysis approaches. IOP Publishing. Broad Exposure to Science and Technology 2019 (BEST2019). IOP Conf. Series: Materials Science and Engineering 673 (2019) 012082.

Ulfah M, Ma'arif S, Sukardi, Rahardja S. 2016. Analysis and improvement of supply chain risk management of refined sugar using house of risk approach. Jurnal Teknologi Industri Pertanian. 26 (1): 87-103.

Vorhies DW, Morgan RE, and Autry CW. 2009. Product-market strategy and the marketing capabilities of the firm: impact on market effectiveness and cash flow performance. strategic management. Jurnal Strategi Manajemen. 30 (12): 1310-1334. 